This article has been published in a revised form in Dance Research Journal https://doi.org/10.1017/ S0149767719000329. This version is free to view and download for private research and study only. Not for re-distribution or re-use. (C) Dance Studies Association 2019. 
Article accepted for publication in Dance Research Journal, December 2019 issue

\section{Im/possible Choreographies: Diffractive Processes and Ethical Entanglements in Current British Dance Practices}

Daniela Perazzo Domm

\section{Introduction: Choreography and Im/possibilities in the Present}

Over the last decade, governmental instability and widespread financial crises both in Britain and in continental Europe have been the background of bewildering events through which problematic political and ethical conjunctures have become day-to-day realities: the refugee crisis, exacerbated by the Syrian civil war and by the measures and legislation implemented in a number of countries to control the flow of migrants; the 2016 British referendum and the civic turmoil and protest marches provoked by the vote to leave the European Union vis-à-vis the xenophobic sentiment it unleashed; London's Grenfell Tower fire on 24 June 2017, which killed over seventy people and injured an equal number among the occupants of this working-class housing complex, leading to public outrage and to demands for independent investigations into building regulations and fire safety. These are but few of the most emblematic events that have brought the question of borders and the issue of difference and discrimination to the forefront of political discourse in the United Kingdom; events that speak of the dangerous unpredictability of contemporary politics and of its increasingly uneasy relationship to ethics. I propose to consider these events as $\mathrm{im} /$ possible realities 1 - insofar as they materialize as situations that are ethically and politically precarious - which demand positioning, and ultimately also action. This article aims to address the question of what choreographic forms such positioning and such action might take, beyond and/or alongside direct political engagement. 
How might choreography attend to the ongoing differentiation and increasing complexity of today's socio-political environment in ways that escape the dominant logic of fear and envision new spaces of commonality? How might dance practices intervene in how causality and agency are conceived of, mobilizing a response as well as a sense of responsibility to the specific configurations that are produced in each spatio-temporal conjuncture? How might choreodramaturgical processes engage with the paradoxical tensions between doing and undoing inscribed in the world's becoming, and grapple with the entanglement of the possible with the impossible? This article approaches the choreographic as a mode of relationality that acknowledges the shifting nature of boundaries and the exclusions implied in any particular encounter, in any specific configuration; it interrogates dance as a site for reorienting horizons of possibility and materializing the workings of the world's ongoing historicity. I propose to think of the precariousness and ambiguity of the events that I sketched above from the perspective of new materialist thought, and specifically through the lens of Karen Barad's notions of indeterminacy and intra-action, which, in dialogue with Donna Haraway's (2004) concept of diffraction, compose an onto-epistemology that is inextricably linked to ethical discourse: an ethico-onto-epistemology. On the one hand, the concept of intra-action - a term coined by Barad - foregrounds the relational aspect of any encounter, challenging the idea of a separation between subject and object and postulating that entities emerge as such through their relations, rather than pre-existing them. On the other hand, as a physical phenomenon diffraction occurs when waves overlap and combine, in the event of interference or when obstructed; as such, it is in itself a form of exchange, which specifically produces differentiation (Barad 2007). Within this framework, the technoscientific understanding of the world that underpins Barad's and Haraway's philosophical perspectives enables a focus on matter, not as an alternative to discourse, but as inseparable from it.2 
This article investigates the potential of a new materialist approach to enable an understanding of a material-discursive practice such as dance. It engages with the interrelation between movement and materiality as a form of ethical engagement with the current socio-political moment enacted through the organization of dancing bodies and choreographic space and the relationship between spectators and participants. Through an a analysis of performances created over the last five years by choreographers working in Britain, it attends to the ways in which their dramaturgies and modes of address embrace indeterminacy and diffraction as essential tools for dealing with differences, interferences and paradoxes. Specifically, the article aims to contribute to the field of recent dance theory and its concern with choreography as a political practice, by interrogating the import of a new materialist perspective for an understanding of how choreographic practices are uniquely positioned to illuminate, comment on and intervene in our appreciation of the relationships between material configurations and historico-political processes. In doing so, this contribution echoes recent compelling examinations of the generative dialogue between new materialist discourse and the creative arts - such as for instance those collected in Estelle Barrett and Barbara Bolt's edited volume Carnal Knowledge: Towards a "New Materialism" Through the Arts (2012) - by foregrounding the urgency with which new materialist thought proposes to address the ethical questions raised by cultural practices and epistemological positions that reinforce and reproduce divisions: between human and nature, between subject and object, between cause and effect.

Within this philosophical framework, the ruptures and improbabilities of day-to-day reality are read as forms of "un/doing," manifestations of "dis/continuity" - "im/possibilities" as Barad (2010) calls them, queering the binary opposition of the two concepts and of their materializations. Attending to some of the processes through which examples of current British experimental choreography reconfigure categories - of time, of space, of relationality, of otherness - I interrogate how these dances not only reflect on the improbabilities, tensions, and 
contradictions that characterize the present moment, but also envision them as methodologies for artistic practice. In particular, I discuss two works: Charlotte Spencer's latest head-phoned production for disused urban spaces Is this a Waste Land? (2017) and Fevered Sleep's creative research and performance project with young girls Men \& Girls Dance (2016). I see these projects as exemplary of what might be identified as a turn in the British choreographic scene, which emphasizes indeterminacy and interaction in the dramaturgical processes by problematizing the material-discursive possibilities of the present. Spencer's participatory group work confronts the stratified spatio-temporality of urban spaces and invites the audience to experience the interconnectedness of their personal and political dimensions. It deals with questions of space, community and belonging, interrogating the distribution and power of boundaries - between inside and outside, between center and periphery. Fevered Sleep's piece interrupts accepted narratives surrounding children's physical and emotional safety and provokes a rethinking of ideas and practices of closeness beyond rhetorics of suspicion and anxiety. It engages with difference by questioning artificial, yet socially- and already ethicallycharged, separations. Both works engage in what can be identified as practices of dissent that actualize the interrelatedness between aesthetic and political activity.

\section{Rethinking Agency: Choreographic Intra-actions}

Writing about the choreographic in the current "moment of cultural crisis," threatened by political and environmental upheaval, Jenn Joy $(2014,1)$ has noted that “[p]erhaps choreography invites a rethinking of orientation in relationship to space, to language, to composition, to articulation, and to ethics." Evoking the precariousness, dissent, and violence that have characterized the first decade of the current millennium, and observing in particular dance- and performance-based works presented on experimental stages in New York and across continental Europe during this timeframe, Joy depicts the choreographic as a modality of "sensual address," as "the movement of embodied thought" (Joy 2014, 1, 23): engaging with 
artistic work that proceeds beyond fixed categories and forms, she constructs choreography as a critical and corporeal practice that thinks and moves through history, society, politics, and aesthetics by activating paradoxical spaces of desire, laughter and violence. Joy opens up the notion of movement-based practice and, drawing on the philosophy of Georges Didi-Huberman and Alain Badiou among others, conceptualizes the choreographic as a "mode of attention" that articulates dance's intrinsic relationality - its unfolding through moving, unstable, undecided relations between thought and practice, between different media, between performer and spectator. Joy's writing constructs the choreographic as that which invites a connection between sensual and critical engagement, foregrounding the affective entanglement of the social with the personal and the ethical positioning it possibilizes.

The "hostile" political and social climate of the first two decades of the twenty-first century is further addressed as the backdrop of the choreographic practices of resistance discussed by André Lepecki (2016, 2) in Singularities: Dance in the Age of Performance. Here Lepecki examines experimental works created in the US, Brazil and Europe over the last fifteen years, which articulate a critical response to the contradictions and conditioning force - the "(il)logic", as he calls it - of late capitalism $(2016,2)$. Specifically, Lepecki argues that, by engaging critically with the notion and practice of performance, experimental dance has begun to expose and undermine the idea of performance as "permanent self-display" that has come to represent neoliberalism's “whole new political condition of power" (Lepecki 2016, 8 original emphasis).3 He draws on Judith Butler and Athena Athanasiou's $(2013,140)$ definition of performativity as "a differential and differentiating process of materializing and mattering, which remains uninsured and unanticipated, persistently and interminably susceptible to the spectral forces of eventness" to postulate the openness, malleability and relational materiality of the choreopolitical gesture of performing freedom. 
Joy's and Lepecki's theorizations of the political significance of contemporary choreography prefigure the reflections I offer in this article, in which I address the modalities through which current dance practices can be seen to engage with growing discourses of separation, inequality and fear of others. Nevertheless, my approach departs from both Joy's and Lepecki's in at least two ways. First, I shift the focus from the Americas and continental Europe to the UK, to interrogate the ways in which British experimental dance responds to the contemporary moment. Second, my contribution offers an alternative mode of conceptualizing how choreography might articulate the relationship between the aesthetic and the political. While Joy and Lepecki, both attending to dance as a critical, ethical and corporeal practice, emphasize, respectively, its capacity for sensuous relationality and its subversion of the category of performance, I propose instead to consider how dance rethinks interaction and agency by engaging in bodily, kinesthetic and dramaturgical interrogations of the paradoxical convergence of the possible with the impossible.

Drawing on Barad's agential realism - a posthuman and new materialist ethico-ontoepistemology - I discuss the creative modalities through which, in the past five years or so, a certain kind of experimental dance in the UK has attended to and engaged with difference and disorientation to rethink ways of acting and interacting in the present. I suggest that the choreographic approaches I examine reframe the space of possibilities that can be actualized at every moment and the notion of responsibility within this process. I propose to reflect on how ethical engagement can be rethought corporeally and dramaturgically, starting from the ways in which, through processes of making, performing, and receiving works of choreography, understandings of difference, models of cohabitation, and patterns of social cohesion are mobilized. Building on, and yet moving beyond poststructuralist conceptualizations of body and discourse, Barad's agential realism reworks crucial notions of agency and causality, subject and object, human and nonhuman, among others, to propose an understanding of matter and 
meaning as entangled. In the choreographic works I discuss in this article, divisions of roles, categories of activity and temporal and spatial boundaries are questioned through a specific use of choreographic principles and dramaturgical dynamics. In Spencer's Is this a Waste Land? the choreography is enacted by both performers and participants through a series of activities in which the distinctions between choreographed and improvised, cause and effect, person and object are blurred. In Fevered Sleep's Men \& Girls Dance the unpredictability of the young performers' behavior and the multiplicity of formats through which the project is made available to a diverse range of audiences highlight the work's openness to indeterminacy and interference.

In turn, the entanglement of phenomena points to ethical implications: insofar as the unfolding of the world's becoming produces both connections and boundaries, inclusions and exclusions, it requires an ethical engagement with the range of configurations that can be realized. In Barad's words, “[d]ifferent material intra-actions produce different materializations of the world, and hence there are specific stakes in how responsiveness is enacted" $(2007,380)$. In referring to "intra-actions," rather than interactions, Barad proposes a relational ontology that moves away from the idea of an encounter of independent and pre-existing entities and points to a specific configuration through which particular phenomena emerge:

A specific intra-action ... enacts an agential cut (in contrast to the Cartesian cut - an inherent distinction - between subject and object) effecting a separation between "subject" and "object." That is, the agential cut enacts a local resolution within the phenomenon of the inherent ontological indeterminacy. In other words, relata do not preexist relations. (Barad 2003, 815 original emphasis)

Within this onto-epistemological framework, the notion of agency is reworked insofar as it cannot be conceived of as a property of an individual subject; instead, agency is to be identified 
in the world's ongoing intra-activity: the world's "dynamism is agency. Agency is not an attribute but the ongoing reconfigurings of the world" (Barad 2003, 818 original emphasis). Separating agency from intentionality and subjectivity, Barad proposes a posthumanist ontology according to which agency involves all matter, all bodies - human and nonhuman. Understood as intervention in the world's phenomena, agency is the actualization of particular possibilities; it entails a response and a responsibility to the particular boundaries and phenomena being configured in each local conjuncture. It becomes ethical engagement insofar as "particular possibilities for (intra-)acting exist at every moment, and these changing possibilities entail an ethical obligation to intra-act responsibly in the world's becoming, to contest and rework what matters and what is excluded from mattering” (Barad 2007, 178). In this article I argue that the particular configurations that are actualized through the choreographies and dramaturgies of the dance works I examine are a way of articulating an ethical response to the range of relations and conditions they operate within.

Rethinking causality and agency in terms of intra-activity, Barad moves toward an "ethics of mattering" in which responsibility is not seen as subjective choice but rather as acknowledgement of the entangled nature of phenomena. While her philosophy builds on among other theoretical insights - Michel Foucault's work on discourse, power and the body, Butler's conceptualization of performativity, Gilles Deleuze and Félix Guattari's concern for immanence, Jacques Derrida's ethics of alterity and Emmanuel Levinas' idea of responsibility to the other, Barad's thought engages specifically with the open-ended nature of processes; it rethinks the relationship between the material and the discursive from a technoscientific and posthumanist perspective that accounts for the production of all matter and phenomena - human and nonhuman. Reflecting on the implications of agential realist thought for the making and understanding of choreographic work, I consider how, in the works I discuss, through the movement and the encounter of bodies and objects, the organization of space and the 
involvement of the audience, conditions of possibility might be materialized which, in configuring specific intra-actions, also account for what is excluded, for the impossible that might have been actualized but was not: as Barad puts it, "[ $t]$ he conditions of possibility of mattering are also conditions of impossibility: intra-actions necessarily entail constitutive exclusions, which constitute an irreducible openness" $(2010,254)$.

\section{Resistance, Responsibility and Recent Choreography in Britain}

A number of contributions to dance and performance scholarship over the last two or three years have endeavored to engage critically with the ways in which movement-based and performative practices respond to, resist or undermine political forces, reckoning with conditions of sociopolitical unrest. Ramsay Burt (2017) examines how, over the last two decades, experimental choreographers in Europe have sought to "ungovern" dance, by enacting a critique of its institutional structures and constraints; The Oxford Handbook of Dance and Politics traces and frames the complex relationships between dance and politics (Kowal, Siegmund and Martin 2017); Tony Fisher and Eve Katsouraki's (2017) edited collection Performing Antagonism considers critical performative practices of resistance to capitalist modes of authority. Similarly, a number of recent conferences and symposia in the UK and beyond have pursued an interrogation of the role of dance in the current historico-political moment in relation, specifically, to late capitalist frameworks ("Dialogues on Dance, Philosophy, and Performance in the Contemporary Neoliberal Moment," Coventry University, 2017), to the cultural, political and pedagogical impasse of the ahistorical present ("Dance in the Age of Forgetfulness," Society for Dance Research, Royal Holloway University of London, 2018) and to notions and situations of conflict (“Contra: Dance \& Conflict," Dance Studies Association, University of Malta, 2018).4 
Writing from the standpoint of a dance and performance studies scholar who is familiar with the British and continental European academic system and performing arts scene, 5 in this contribution I focus on recent experimental choreography in Britain with the awareness that it often features only marginally in the circuit of international festivals and, to some extent, in critical scholarship, including Anglophone. What I offer in this article is a reflection sparked by a number of movement-based works staged in and around London over the last few years, which have led me to interrogate the creative-critical capacity of choreography to respond to the current socio-political moment. These dance dramaturgies draw on a broad set of parameters (sometimes shared, sometimes more idiosyncratic); yet a common thread between them can be found in how they demand that we attend to differences and their complexities. In dialogue with the ethical discourse that emerges from Barad's agential realism, I argue that, by embracing disorientation, staging im/possibilities and reimagining history, memory and experience, these recent movement-based works are in themselves ways of being "responsive to" and of taking "responsibility for" the world we live in (Barad 2010, 266).

While the discussion that follows focuses in particular on Spencer's Is this a Waste Land? and Fevered Sleep's Men \& Girls Dance, the thinking that underpins this article stems also from broader reflections on a diverse range of experimental solo and group pieces by UK-based dance artists, between well-known and emerging choreographers, encompassing works involving different media, formats and framings, from videos to live theater pieces, from durational performances to site-responsive choreographic events. I am thinking, for instance, of Siobhan Davies and David Hinton's film installation The Running Tongue (2016), a collaboration with twenty-two dance artists that, in depicting the journey of a running woman against a backdrop of ever-changing “visions” (Davies, Hinton and Ellis 2015, 83), makes use of a live editing software that rearranges the frames at random at each projection, producing a kaleidoscopic rendition of the paradoxical, yet generatively indeterminate nature of choices and relationships. I 
am also thinking of Jonathan Burrows, Matteo Fargion and Hugo Glendinning's project 52 Portraits (2016), which, through a series of video portraits of performance artists released online one by one each Monday of 2016, combines gestural movement and song to underscore the "interplay between movement, choreography, and self-expression" (Blades 2017, 100) and the productive relationship between individuality and plurality. Other examples include: Rita Marcalo/Instant Dissidence's Dancing With Strangers: From England to Calais (2016), which imagines encounters between refugees in the Calais Jungle and people on the streets of British towns, staging impromptu duets that re-enact the materiality of the meeting and envision new possibilities of exchange; Amy Bell's Tombo(y)la (2017), subtitled “A conversation with a dancer dancing in conversation with their gender; A rolling archive of tomboyhood; A drop-in durational installation" (Bell n.d.), in which, moving and talking among audience members in response to written questions and messages extracted from a tombola drum, Bell experiments with forms of storytelling of social subjectivities to rethink gender categories; Project O's Voodoo (2017), a durational work performed over the course of eight hours (experienced as a two-hour event by four sets of spectators) by Alexandrina Hemsley and Jamila Johnson-Small who invite the audience to a shamanic experience which weaves together political and personal narratives of black history.

The fact that these works adopt different framings, modalities of address and media is methodologically significant for my argument. I suggest that these dance projects diffract patterns of spatiality and relationality, codes of togetherness, and models of choreographic work. As Barad (2007) points out, as a physical process, diffraction functions very differently from reflection: while reflection implies a mirroring, diffraction results from interference and produces differentiation. In relation to the choreographies I examine, I consider how, by employing transformative creative processes or assuming destabilizing conceptual premises, they unsettle dominant social and political narratives and bring to the foreground the intrinsic 
plurality and fluidity of constructs of identity and community. My claim is that these works represent compelling examples of how movement-based practices might offer re-imaginings of the present as articulations of an ethical commitment to local conjunctures: they exemplify how we might not just conceptualize, but also materialize the world differently.

\section{Diffraction, Difference and Dance}

New materialist thought and posthumanist perspectives have been called upon in recent performance scholarship to account for performance practices that question anthropocentrism and extend the range of performing bodies beyond the human. Respectively mapping the emergent convergence of new materialism with performance studies and proposing a new materialist theoretical lens for the understanding of performance work, Rebecca Schneider (2015) and Theron Schmidt (2017) both invoke William Connolly's definition of new materialism as

a series of movements in several fields that criticize anthropocentrism, rethink subjectivity by playing up the role of inhuman forces within the human, emphasize the self-organizing powers of several nonhuman processes, explore dissonant relations between those processes and cultural practice, rethink the sources of ethics, and commend the need to fold a planetary dimension more actively and regularly into studies of global, interstate and state politics. (Connolly 2013, 399)

Both Schneider and Schmidt discuss the question of the distribution of agency - including via Jane Bennett's notion of "distributive agency" (2010) - and problematize how performance theory and practice engage with its extension to nonhuman forces. 
The intersection of human and nonhuman agency variously features in the choreographic works I refer to in this article. For instance, the live editing of Davies and Hinton's The Running Tongue entrusts the order of the narrative to a computer program at each new projection of the film; the dramaturgy of Bell's performance-installation Tombo $(y)$ la revolves around the spinning of a tombola drum by a member of the audience and the extraction of written messages which prompt Bell's movement and verbal response; the online circulation and serial structure of Burrows, Fargion and Glendinning's video project 52 Portraits extends the notion of selfportraiture beyond the featured individuals and possibilizes an artistic community through the virtual durational catalogue it stages.6 Nevertheless, in considering the reformulation of the idea of agency that these works actualize, I am especially drawn to how this reframing unfolds in the works through their dramaturgies (of performance and/or reception), rather than necessarily through the use of technology. In this respect, my contribution is prefigured by Amelia Jones' new-materialist-informed analysis of hybrid and performative art practices which draws attention to the material processes through which they come to be what they are - to the workings of the work of art, or as Jones puts it, to its "having been made" (2015, 23 original emphasis). Tracing the emergence of new concepts of agency in these practices, Jones focuses on how the artworks "indicat[e] previous processes of making" rather than offering themselves "as static and immutable" (2015, 23 original emphasis). In a similar way, I engage with how Spencer's and Fevered Sleep's choreographic practices make their own processes of making visible. In particular, I attend to how such making engages with differentiation through what, in new materialist terms, can be identified as a diffractive approach.7 In adopting this term, I foreground the ways in which the dance works I examine account for interference and indeterminacy in their creative and dramaturgical processes, thus multiplying and overlapping possibilities rather than duplicating or displacing sameness. 
Following Barad $(2007,88)$, who, in Meeting the Universe Halfway, makes it clear that diffraction is not used as an "analogical" method to illustrate from the outside the ways in which the world works, I suggest that diffraction can illuminate the material-discursive phenomena that make up choreographic work, the "entanglement of matter and meaning" - to borrow Barad's phrase from the book's subtitle - that is produced by relationalities and differences: between thinking bodies, through space-time configurations and in the thinking-practicing of performance. Disrupting traditional ideas of temporality, spatiality and materiality, quantum entanglements diffract notions of here-now, there-then and cause-effect, conjuring a field of dis/continuous occurrences. Barad's argument, which challenges dualistic interpretations of matter and meaning, also points to the destabilizing and trans/formative nature of quantum processes, through which historical narratives are unsettled and identities are un/done. In this respect, Barad's notion of diffraction employs a techno-scientific term to articulate a materialist reading of Derrida's idea of alterity: “To think the 'holding together' of the disparate itself. Not to maintain together the disparate, but to put ourselves there where the disparate itself holds together, without wounding the dis-jointure, the dispersion, or the difference, without effacing the heterogeneity of the other" (Derrida 1994, 29 original emphasis). Barad's diffraction accounts for the heterogeneity of space, time and matter and their entanglement.

These are some of the considerations that underpin the line of thinking of an ethics of diffraction - an understanding of the "entangled nature of nature," the idea that "it matters at every moment how we (en)act (in) this world" (Thiele 2016, original emphasis). As Kathrin Thiele puts it, in her compelling reading of Barad's quantum ontology alongside Deleuze's philosophy of difference, "a thought based on 'difference in itself' is always/already (ethically) concerned or charged" (2016, original emphasis). This in turn "moves the ethical discourse from one focused on the right conduct (assumed or given), towards one that exposes itself to the real precariousness and ambiguity of each and every of our practices" (Thiele 2016). As Thiele 
argues, the acknowledgement of this precariousness does not lead to relativism and lack of ethical concern. On the contrary, for Haraway it leads to the idea of "response-ability," to a commitment "to making a difference" (Haraway in Thiele 2016). For Barad $(2007,89)$, it means "taking responsibility for the fact that our practices matter," as "the world is materialized differently through different practices."

\section{Re-choreographing Boundaries: Is this a Waste Land? by Charlotte Spencer Projects}

The version of Spencer's8 Is this a Waste Land? I attend takes place in the center of Corby, Northamptonshire - just over an hour north of London by train. The meeting point is the car park of the Savoy Cinema, a multi-screen movie theater of recent construction, adjacent to Corby's main retail, leisure, and restaurant area. The event itself happens in a large disused, fenced-off space opposite the cinema, backing onto Corby Central Park and the no-man's-land of illegal sheds wedged between the two. It is the work's official premiere, on April 29, 2017, and it is set to go ahead in all weathers.9 We are asked to dress for an outdoor performance which will require us, the audience, to move and be active on an uneven and possibly wet ground. We are also asked to bring "an unwanted object to donate to the performance - this could be anything from an old bucket to a piece of wood, a bike tyre to an old brush!" (Deep Roots Tall Trees 2017).

I forget to bring my object - too concerned with my travel arrangements, perhaps. I feel disappointed as this seemed so significant for the ethos of the work, which does not invite the paying audience to come and consume the show, but engages spectators and performers - both participants in this immersive head-phoned performance 10 - in the circular experience of giving. The gift is to become part not only of that particular instantiation of the piece but also of its future iterations, as each donated object is added to the collection of materials that make up the work and will continue to inhabit it. Luckily, my careful travel planning means that I arrive 
early: looking for the entrance to the performance area, I see a man waiting outside a gate, holding a pair of old flippers. We are the first ones there and making conversation seems both appropriate and inevitable. He is proud of his gift and tells me there is a skip bin at the back of the car park where I might find something too. I come back with some unremarkable pieces of metal and plastic, which will be my meagre offerings. He tells me he is a local; he has heard from friends who work nearby that a group of young people has been living for weeks in this abandoned site in the middle of the town. What have they been up to? The curiosity was enough to make him come and see for himself. When the gate opens and a few other spectators/participants arrive, it is clear that this is a heterogeneous audience: young, artsylooking people alongside older folks in more formal clothes, and even what looks like a ladiesnight-out group, with a couple of women in white trousers and high heels (who clearly were not informed of the dress-code recommendations).

We are given a pair of work gloves and a set of headphones. Building on the model of her earlier Walking Stories (2013),11 Spencer's Is this a Waste Land? uses digital audio technology to engage the audience in the exploration of public space - parks and green areas in the earlier work and neglected urban plots in this new one. As the audio playback begins, the recorded voice asks us to form a line: holding the object we have been asked to select from a collection of unwanted items (not necessarily the one we brought), we face the seemingly unexceptional sight of the wasteland that stretches in front of us. We move forward. We are a group of around forty on a mission to explore (rescue? Redeem? Expose?) this unattended piece of land, sitting shamefully next to a busy and respectable area of town. The performers are among us, moving and doing alongside the audience/participants rather than leading them. It is not long before the group loses cohesion and we start to disperse: through the headphones we are wearing, we are asked to find a special spot, stop and look; we are instructed to trace or retrace our steps, to congregate where others are converging, or to move away from people and things: tasks are 
imparted that make us busy - carrying objects, moving them from place to place, raising fences, holding poles, pulling ropes.

\section{[Photo 1]}

Whenever I look around, not everyone around me is engaged in the same task as me. How did those people end up on that mound? Did I miss a cue? Devised for up to eighty audience members, the head-phoned performance is organized around multiple strands, which arrange and rearrange the participants into groupings and allow the work to be shaped by uncertainty to a large degree. In a podcast recorded days before the premiere in April 2017, Spencer reflects on the indeterminacy of the work; she says: "it's a very interesting process, because we have to imagine it; we can't actually try it until it's being performed ... . I don't know what I've made yet, until we see it with people in it .... And we can't even do a dress rehearsal, because the performers ... do different things from what the audience-strands that they are kind of accompanying do" (Spencer 2017a). Whatever we build, alone or together, is dismantled or remolded into something else: the space around us is in constant flux; its features are made visible by our doing only to be eclipsed by another cluster of activity which draws attention to a different aspect of this stratified place, whose history is entangled in its layers of rubble and detritus. 12

In the program notes accompanying the performance, Spencer makes reference to the context in which the first idea of the work emerged and places its starting point

in 2013 during a cycle tour across England and France whilst making my previous work, Walking Stories. We stumbled across all kinds of spaces that usually get by-passed by motorways, railway routes and the general haste of life. As cities spilled out into countryside we crossed hinterlands, edgelands, dumps, waste disposal units, nothingy places, in-between, left behind spaces. I was drawn to them. (Spencer 2017b) 
Writing about the disused spaces she travelled through, Spencer notes: "I started to imagine how it would be to create a performance for one such place. Somewhere that people don't normally go to" (Spencer 2017b). In her company's online blog, she reflects on the past-present-future of these liminal zones, these boundaries:

And so I find myself left considering, what might have happened here 10, 100, 1000 years ago? What did it look like? Trees exchanged for concrete, wild activity replaced by human activity. Productivity. Futures. Making, busying. Now gone. Abandoned. If we leave it long enough where will the trees grow? How long will they take? How many people will pass over? (Charlotte Spencer Projects 2015)

As the performative event unfolds, we are in turn included and excluded by every new configuration; as we carry planks, pallets and ropes and use them to delimit sections of the vast space, we find ourselves this or that side of a boundary. As head-phoned participants, we are instructed and/or decide to walk, run, sit, turn, bend, collect things, build towers, pull ropes, hold poles: engaging in the series of activities choreographed by the audio-recording, we are immersed in space and its social structures. Most importantly, we do not simply perceive them, or move within them; we produce them; we enact their possibilities. I suggest that, by inviting the audience to join the performers and other participants in a series of tasks, the work exposes different understandings of individuality and togetherness, of the role and function of rules, of the purpose of human activity, of the cyclical nature of our doing and/as undoing. Through an intra-active engagement with the principles and mechanics of group activity, the performance re-materializes the workings of social interaction. In this sense, the piece addresses questions of movement and mobility, inclusion and exclusion, by intervening in their semantic and ethical articulation: what does it mean to move and be moved, or even to be made to move? What is the 
significance, the impact of the boundaries we create, of the fences we build, for ourselves and for others? Our material involvement in the situation that is being configured is exposed: we are entangled in processes of making, beyond conventional understandings of agency and clear distinctions of cause and effect.

Some tasks are carried out individually: we are sent on a search and, although we perceive that a few others have received the same instruction, it is up to us how we go about it. Other tasks require us to collaborate: we are expected to join forces, to coordinate movements, so that a large circle can form, a rope can be held in tension, long poles can be passed around. As I offer my attention to the voice that speaks in my ears, to the layers of sounds that accompany it and to the intriguing array of activities that unfold around me, a thought starts forming about how literally I am supposed to obey the instructions I receive. The audio recording gives us permission also not to follow them. The tower I am building with a few others (no communication between us: we seem to be part of the same audio strand) keeps collapsing: do I overcome the frustration and find a way to make it work or do I stop and watch, or even find something else to do? I wonder how others experience this tension between following and disregarding instructions, between being both inside and outside what is materializing. In fact, occasionally I see individual participants isolating themselves: moving further away or not contributing to the task at hand. How do we respond to authority? And what happens when we do not observe the rules? What does our relationship with obedience or disobedience produce? The tower I have been working on is improving. Piling waste materials, we are collectively managing to balance them better. I realize I care more and more about the success of our task, so the next instruction throws me off balance: we are asked to pull the tower down. After all that effort, it is hard to watch it crash to the ground. 
By engaging with, and involving the audience in, the re-configuration of what, in Barad's terms, can be considered as material-discursive phenomena, the work responds to dominant conceptualizations of democratic politics and takes responsibility for challenging them. I suggest that the project embraces diffraction and intra-action as creative methodologies that inform both the process of making and the work as it is performed and experienced. Is this a Waste Land? engages with difference by questioning it but also by producing it; it highlights difference not only by drawing our attention to its existence, but also by showing us how difference is enacted and by involving us in its production. In this sense, it does more than denouncing boundaries; it acknowledges their ongoing redistribution through a process of differentiation which the audience/participants are exposed to, both visually and experientially. In doing so, Spencer's immersive project offers an opportunity to see and live differencing mechanisms and to reflect on the entangled nature of socio-historical phenomena - on how we contribute to the ways in which possibilities are conceived and enacted, made and unmade.

At the end of the performance, once we have returned headphones and gloves and are now acting outside of the carefully crafted, yet still largely unpredictable, intra-actions we have participated in, performers and spectators are invited to gather around a campfire, where tea and biscuits are passed around. It is an opportunity to talk about what we have experienced, to voice the questions that we might have been grappling with, or simply to share a moment of conviviality in a place that, outside the frame of the performance event, is emptied of conventional forms of social life. As the audio recording pointed out, if we entered this same space tomorrow, we would be trespassing. The possibilities we are attending to today are entangled with the im/possibilities of yesterday and of tomorrow.

I am drawn to Spencer's work as an "agential cut," as a gesture that provides momentary legibility to the indeterminate heterogeneity of the spatio-temporal (and both personal and 
political) reality of urban spaces. In order to tell a story of this disused land, Spencer invites the audience to interact with the entangled layers of a city. Is this a Waste Land? does not presume to resolve the city's contradictions and paradoxes; rather, it summons performers and spectators to participate in its becoming, to be involved in its future by engaging with its "fragments, traces, footprints, memories" (Charlotte Spencer Projects 2015) from the past and intra-acting with its materiality in the present. In Spencer's words from a blog post written while working on the project, there are many things that choreography can $d o$ in the present:

We're building
living
occupying
protesting
watching
wondering
enduring
destroying
clambering
clearing
cleansing
listening
being here today with you
imagining
re-imagining

We need visionaries. (Charlotte Spencer Projects 2015) 


\section{Reclaiming Closeness: Men \& Girls Dance by Fevered Sleep}

The foyer of The Place theater, London, is crowded with children, teens and their families, alongside what I recognize as a more typical contemporary dance audience. It seems that many families and friends have come to see and support the young performers of Fevered Sleep's Men \& Girls Dance, a piece that brings together "five professional male dancers and nine girls who dance for fun" (Fevered Sleep 2017, 1).13 As the audience take their seats in the auditorium, on stage the male dancers and the pre-adolescent girls, dressed in everyday clothes, are taping sheets of newspaper to each other, covering a rectangular area of the floor with studied yet playful precision. The adults, in their late twenties to early forties, seem in charge, but only just, as the girls' energy in carrying out the tasks (a mixture of excitement and nerves) brings these simple actions to life. According to the front page of the London edition of the newspaper published by the company as part of the project, the work "reclaims the rights of adults and children to be together, to play together and to dance together" (Fevered Sleep 2017, 1).

The project has so far unfolded as a series of research and development periods, which began in 2013, as a number of performance residencies in the UK, as post-show debates with local venues and audiences, and as a newspaper, in various local editions, which collects artists' writings, words from the show, reflections on the work and its themes written by the participants and by observers from local or artistic communities, alongside extracts from codes of conduct and guidance for safe working practice in education. In this sense, while the piece I saw was performed in a theater setting, the work itself exists "across the totality of its multiple material instantiations" - through what Peter Osborne defines as the "distributive unity" of contemporary artworks $(2013,48)$. As a performance, the project has also been staged in less conventional settings, such as sports halls, community centers and, in Summer 2017, the 1840 display room at London's Tate Britain. Together with the transgenerationality of the piece's performers and intended audience, the transmediality and transcategoriality of the work support the reading of 
its diffractive aspects I construct in this article. The (controlled) unpredictability of the children (in their encounter with the professional dancers and with the audience) and the variety of channels through which the work is created and experienced (as outlined above) signal an openness to multiplicity and prefigure indeterminacy and interference in its performance and reception.

Once the large newspaper 'blanket' is ready, the performers arrange themselves along two opposite sides: adult men on the left, young girls on the right. They watch and study each other: little by little, the girls' growing sense of curiosity and the men's unhurried demeanor and approachable attitude lead to the staging of moments of encounter. In all likelihood, these configurations draw on the phases of the journey of mutual discovery the performers experienced during the research and development phase, thus gesturing towards the project's processes of making - what Jones $(2015,32)$ calls "the work of its having been made." The first contact is channeled through the large newspaper sheet, which is held on all sides and gently shaken in the air; this soon becomes the pretext for a game of hide and seek and the stage is quickly filled with dynamic, nimble movement and laughter. More newspaper makes up the setting: there are pages crumpled up on the floor upstage or neatly arranged in overlapping pattern on a vertical panel to form a backdrop.

In the piece, newspaper is both an eclectic material that lends itself to being used for playful activities (from fighting with paper balls to playing catch wearing a paper-molded monster head) and a reference to the media and the negative narrative they construct surrounding the risks and inappropriateness of the relationship between men and young girls - the monster head worn by one of the male dancers evoking images of child molesters. Both the writings collected by Fevered Sleep (2017) and video interviews with their artistic directors David Harradine and Sam Butler14 frame the project as a response to this kind of social discourse. In their words, the 
project is "an exploration of closeness and of relationships, and of our perceptions of what it means for men and girls to come together in this way at this time" (Fevered Sleep 2017). The performance embarks on the sensitive project of reconfiguring what in today's world might be read as a social and moral impossibility: the closeness between men and young girls, through bodily and sensorial contact. Through dancing, the work attempts to reframe the ethical question about this relationship by focusing on its potentialities for playful and nurturing togetherness.

Physical contact is explored in the dancing first and foremost through lifting, which, executed in unpredictable and unconventional ways, foregrounds the feeling of abandon and exhilaration of the young girls who look as if they could fly through the air and feel as if (in the words of one of the participants) they were "in loads of different places at once" (Fevered Sleep 2017, 27). In these moments, the gestures of the strong adult males do not produce antithetical images of powerless, fragile little girls. The lively and audacious lifts and holds catalyze qualities such as trust, complicity, playfulness. There are also other forms of touch: the men and the girls hold hands, whisper into each other's ears, lean onto each other's bodies, look into each other's eyes. The piece adopts a diffractive approach to the production of performance roles and their movement qualities, mobilizing a rethinking of these gender and generational categories and of the differences and similarities conventionally associated with them. Instead of assuming that 'adult male' and 'young girl' are pre-existing entities that can be presented or represented in performance, it produces them through the performing itself and foregrounds the shifting nature of their boundaries. The dance visualizes and materializes the inherent indeterminacy of these categories, embracing the Baradian idea that phenomena are constituted through relations. The piece also reveals that the way in which these categories are produced matters, as every configuration implies the exclusion of other possibilities.

\section{[Photo 2]}


As I watch, I reflect on how significant this experience is likely to be for the young female performers: learning to trust an older person of the opposite sex might also teach them to be more discerning in critical circumstances. On my way home after the performance, I think of the power of touch and of how, for little children, it is the primary way of experiencing the world, of learning. I think of Barad's $(2012,214)$ quantum-theory-informed definition of touch as always "entail[ing] an infinite alterity" - what Derrida calls "the certainty that touching ... touches the heart and on the heart, but inasmuch as it is always the heart of the other" (2005, 274 original emphasis).15 Reading Derrida's reflections on touch in light of the "transience of matter's existence” (Barad 2012, 209), Barad writes about touch as an issue concerning “disciplinary knowledge formations, political parties, religious and cultural traditions, infectious disease authorities, immigration officials, and policy makers” $(2012,206)$. In relation to children, touch is a delicate issue, often at the center of welfare policies in educational environments. The Men \& Girls Dance newspaper (Fevered Sleep 2017, 13) reports an extract from an "appropriate touch" policy issued by a school for girls in England:

There is no area more sensitive and difficult to provide guidance for than the issue of "touch" with pupils. ... When comforting or supporting a pupil do not touch any parts of her body, other than the hands, arms, shoulder area and top of the back. Touch will rarely be appropriate if it involves any other parts of the body. (Moira House 2013)

The policy makes clear reference to how, although "appropriate touching initiated by pupils should be recognized as a part of normal relationships," physical contact "could invoke sexual feelings," could make a pupil feel "uncomfortable" or could be "misunderstood" (Moira House 2013). Touching always involves a risky encounter with the unknown, including the unknown within oneself. In foregrounding touch and in accepting its risks, Fevered Sleep think and act beyond divisions (between subject and object, between categories of the human) in a new 
materialist sense. In Men \& Girls Dance, touch is a mode of encounter that produces the intraacting subjects, inasmuch as men and girls are local subjectivities that come into existence within the piece through their physical exchanges.

This interplay of known and unknown, of self and other, of inside and outside the social and moral boundaries of our codes of conduct is explored in Men \& Girls Dance through both movement and text. As in Spencer's work, movement and words intersect in Fevered Sleep's performance. Spoken text inhabits the piece alongside the dancing and is delivered with or without a microphone by both the adults and the children, as well as being played back from audio recordings.16 Alongside more formally set-up scenes in which scores are danced or spoken, the performance has the quality and openness of a workshop activity, in which ideas are tested and there is a shared feeling of excitement about the unpredictable experiences and unknown discoveries that might emerge through the process. Its undoing of social taboos and anxieties does not deny that in many cases these may be justified: rather, it has the abandon of a child's unrestrained playfulness and the judgement of an adult's refusal to abide by an undiscerning rule.

A male performer sits next to a girl and studies her closely, examining minute details of her face and body and establishing physical closeness. As he does so, he speaks softly through the microphone:

I can see her freckles

I can see the hairband around her wrist

I can feel the knuckles in the back of her hand

I can see the mark on her right arm, on her elbow

I can hear her breathe 
I can see her flaring her nostrils

I can see her wobbly tooth in her mouth

I can hear her heart beat

I can feel the warmth of her skin against my face ...

And then, facing the audience: "I can see you watching me" (Fevered Sleep 2017, 4). While these words intersect with personal and collective images and stories of sexually-charged, if not abusive, situations between men and young girls, they also materialize different possibilities, of ways of interacting based on trust and enjoyable playfulness. They evoke touch (through physical proximity, gaze and emotional intimacy) as an experience that, in Barad's $(2012,208)$ words, "moves and affects what it effects," while also problematizing the relationship of causality we implicitly attribute to it, the roles we see implicated in it. Who is touched by whom, if touching always involves contact with alterity, if matter is transient and indeterminate?

Later in the performance, the roles intersect and overlap and a young girl sits next to a male dancer, his torso reclined on her legs; she examines details of his body and speaks her touch: "I can see the wrinkles on his elbow; I can feel the weight of him on me; I can see some moles on his arm; I can feel his curly beard; I can see his face is a bit sweaty ...." More than a simple reversal, a mirroring of antithetical positions, her words continue to complicate our reading of this touch, continue to diffract it: touch as care, as curiosity, as vulnerability, as risk, as confusion, as play, as danger, as comfort, as power, as love. The experience of physical and emotional intimacy and ease between the adult males and the primary-school-aged girls in the show has the potential to interfere with and destabilize fixed understandings of difference as a justification for universal fear and distance. The piece is as much a joyful event as it is a serious attempt to think the unthinkable: it does not erase important concerns surrounding the safety of young people, but through the dancing together of men and girls who learn each other's steps, 
take turns in leading and following and respond to each other's gestures, looks, and words, it materializes possibilities that account for what is excluded by the bans resulting from unidirectional reactions to fear.

To a degree, a more black-and-white approach transpires from the deliberate way in which the reframing of categories the piece promotes is presented in stark opposition to dominant narratives and safeguarding policies surrounding the relationship between men and girls, which emphasize fear and inappropriateness. This occurs principally in the verbal discourse that accompanies the performance (in writing and in audiovisual recordings). For instance, in a Men \& Girls Dance trailer (Fevered Sleep 2016), the company's artistic directors talk about how the project "invites people to think and talk about the way that men and girls can be together in more positive ways, in more normal ways" (Butler) and how "there are many ways of being together ... and, generally, those ways are wholly positive" (Harradine). In this sense, the verbal commentary of the work appears, to some extent, to curb the diffractive potential of the project, producing instead a refraction of the perceived social problem the project sets out to question into its specular opposite: an image of normality and wholesale positivity.

Yet, in its encounter with the audience the work goes beyond the humanistic gesture that seems to be at the center of the company's intentions. It involves matter and/as discourse; through an intra-active engagement with the conventional bodily and theoretical apparatus that constructs the relationship between young girls and older men as inappropriate, it affirms the possibility of re-materializing it and re-conceptualizing it. In endeavoring to address the material-discursive phenomenon of the relationship between adult males and schoolgirls, the work intervenes in the semantic and ethical articulation of the issue by re-configuring the properties and boundaries that define it. It responds to the presumed fixed configuration of the phenomenon and takes responsibility for troubling it. It reclaims a space for emotional and physical closeness between 
men and girls where a range of possibilities can be explored in which formats and ideas conventionally excluded from dominant social behavior and discourse overlap with accepted ones.

\section{Conclusion: Dance's Ethical Entanglements}

The works I have discussed in this article are compelling examples of the ways in which dance practices engage with the ethical possibilities that rethinking difference and boundaries opens up. Discussing Barad's ethos of diffraction, Thiele $(2014,202)$ asks: "how to live a world of difference(s), a world in/as ongoing differentiation, in such ways that the outcome is not ever more separation and antagonism, exclusion and the fear of others, but so that new senses of commonality are envisioned?" In the face of an often reinforced dominant binary logic in response to experiences of difference, these dance works attempt to engage with this question by dis/orienting horizons and envisioning im/possible outcomes. They involve an ethical commitment that acknowledges that "ethics is not simply about the subsequent consequences of our ways of interacting with the world, as if effect followed cause in a linear chain of events" (Barad 2007, 384); instead, their ethical approach entails opening up to indeterminacy in the process and experience of performance.

Furthering existing conceptualizations - Lepecki's and Joy's among others - of choreographic practices that engage critically, politically and affectively with the complexities and contradictions of the present, I maintain that these works' commitment to the socio-political question of difference is ethical because, through methodologies that privilege diffraction and intra-action, these projects reorient horizons of possibilities and produce new materialdiscursive configurations from which to experience and understand the present. Moreover, in questioning the permanence of borders and in understanding boundaries as zones of contact, these choreographies attempt to reconfigure not only the performer-audience connection, but 
also the notion and composition of a dance audience, reaching beyond the artificial remit of what is conventionally identified as the dance world.

\section{Acknowledgements}

I would like to thank my anonymous readers for their rigorous, generous and critically constructive feedback during the peer review process. I am also grateful to Kélina Gotman for her insightful comments on an earlier draft of this article, to Vicky Hunter and Theron Schmidt for stimulating conversations on dance and new materialism, and to Arabella Stanger for inspiring my thinking on the materiality of choreographic space. Thank you to Charlotte Spencer and Fevered Sleep for facilitating the research that underpins this piece of writing and for granting me permission to use the images that illustrate it.

\section{Works Cited}

Barad, Karen. 2003. "Posthumanist Performativity: Toward an Understanding of How Matter Comes to Matter." Signs: Journal of Women in Culture and Society 28 (3): 801-31. https://doi.org/10.1086/345321.

Barad, Karen. 2007. Meeting the Universe Halfway: Quantum Physics and the Entanglement of Matter and Meaning. Durham and London: Duke University Press.

Barad, Karen. 2010. “Quantum Entanglements and Hauntological Relations of Inheritance: Dis/continuities, SpaceTime Enfoldings, and Justice-to-Come.” Derrida Today 3 (2): 240-268. https://doi.org/10.3366/E1754850010000813. 
Barad, Karen. 2012. "On Touching: The Inhuman That Therefore I Am.” differences 23 (3): 206-223. https://doi.org/10.1215/10407391-1892943.

Barrett, Estelle, and Barbara Bolt, eds. 2012. Carnal Knowledge: Towards a "New Materialism” Through the Arts. London and New York: I.B. Tauris.

Bell, Amy. n.d. “Tomboyla.” Accessed November 7, 2017. http://tomboyla.com/about/.

Bennett, Jane. 2010. Vibrant Matter: A Political Ecology of Things. Durham: Duke University Press.

Blades, Hetty. 2017. "Screendance Self/portraits.” The International Journal of Screendance 8: 93-103. http://dx.doi.org/10.18061/ijsd.v8i0.

Burrows, Jonathan, Matteo Fargion, and Hugo Glendinning. 2016. "52 Portraits.” Accessed May 15, 2018. http://52portraits.co.uk.

Burt, Ramsay. 2017. Ungoverning Dance: Contemporary European Theatre Dance and The Commons. Oxford and New York: Oxford University Press.

Butler, Judith and Athena Athanasiou. 2013. Dispossession: The Performative in the Political. Cambridge, UK; Malden, MA: Polity Press.

Charlotte Spencer Projects. 2015. “Waste.” Posted April 2, 2015. Accessed November 7, 2017. https://charlottespencerprojects.org/tag/itawl/. 
Connolly, William E. 2013. “The 'New Materialism' and the Fragility of Things.” Millennium: Journal of International Studies 41 (3): 399-412. https://doi.org/10.1177/0305829813486849.

Daddario, Will, and Theron Schmidt, eds. 2018. “Crisis/Krisis.” Performance Philosophy 4 (1). https://doi.org/10.21476/PP.2018.41225

Davies, Siobhan, David Hinton, and Simon Ellis. 2015. "The Running Tongue: Collaboration, Choice, and Community. Siobhan Davies and David Hinton, in conversation with Simon Ellis. Thursday 6th February 2015.” The International Journal of Screendance 5: 83-94. http://dx.doi.org/10.18061/ijsd.v5i0.

Deep Roots Tall Trees. 2017. “Our Woods: Is This a Waste Land?” Accessed May 15, 2018. http://deeprootstalltrees.org/our-woods/people-involved/charlotte-spencer/is-this-wasteland/.

Derrida, Jacques. 1994. Specters of Marx: The State of the Debt, the Work of Mourning, \& the New International. Translated by Peggy Kamuf. New York: Routledge.

Derrida, Jacques. 2005. On Touching - Jean-Luc Nancy. Translated by Christine Irizarry. Stanford: Stanford University Press.

Farnham Maltings. 2015. “Greenhouse: Men \& Girls Dance.” Accessed May 21, 2018. https://www.youtube.com/watch?v=jZZuMdXqinM.

Fevered Sleep. 2016. “Men \& Girls Dance: Trailer.” Accessed May 21, 2018. https://vimeo.com/153937408. 
Fevered Sleep. 2017. "Men \& Girls Dance (London edn)."

http://www.feveredsleep.co.uk/current/men-and-girls-dance/.

Fisher, Tony, and Eve Katsouraki, eds. 2017. Performing Antagonism: Theatre, Performance \& Radical Democracy. London: Palgrave Macmillan.

Haraway, Donna. 2004. The Haraway Reader. New York and London: Routledge.

Harpin, Anna and Helen Nicholson, ed. 2016. Performance and Participation: Practices, Audiences, Politics. Basingstoke: Palgrave Macmillan.

Jones, Amelia. 2015. 'Material Traces: Performativity, Artistic 'Work,' and New Concepts of Agency." TDR: The Drama Review 59 (4): 18-35. https://doi.org/10.1162/DRAM_a_00494.

Joy, Jenn. 2014. The Choreographic. Cambridge, Massachusetts: The MIT Press.

Juelskjaer, Malou and Nete Schwennesen. 2012. "Intra-active Entanglements: An Interview with Karen Barad.” Kvinder, Kфn \& Forskning 1-2: 10 - 24. Accessed June 2, 2018. https://www.researchgate.net/publication/267863856_Intraactive_entanglements_an_interview_with_Karen_Barad Kowal, Rebekah J., Gerald Siegmund, and Randy Martin, eds. 2017. The Oxford Handbook of Dance and Politics. New York: Oxford University Press.

Lepecki, André. 2016. Singularities: Dance in the Age of Performance. London and New York: Routledge. 
Moira House. 2013. “Appropriate Touch.” Accessed June 2, 2018.

http://www.moirahouse.co.uk/wp-content/uploads/2014/11/appropriate-touch.pdf

Osborne, Peter. 2013. Anywhere or Not at All: Philosophy of Contemporary Art. London and New York: Verso.

Perazzo Domm, Daniela. 2017. “The 'making' of movement and words: a po(i)etic reading of Charlotte Spencer's Walking Stories.” Choreographic Practices 8 (1): 111-130. https://doi.org/10.1386/chor.8.1.111_1.

Perazzo Domm, Daniela. 2018. "Crisis and the Emotional Body: Towards (Another) Freedom." Performance Philosophy 4 (1): 188-205. https://doi.org/10.21476/PP.2018.41196.

Rancière, Jacques. 2009. The Emancipated Spectator. Translated by Gregory Elliott. London: Verso.

Schmidt, Theron. 2017. "What Kind of Work Is This? Performance and Materialisms in the Gallery.” Performance Paradigm 13: 7-28. Accessed May 15, 2018. http://performanceparadigm.net/index.php/journal/article/view/191.

Schneider, Rebecca. 2015. "New Materialisms and Performance Studies." TDR: The Drama Review 59 (4): 7-17. https://doi.org/10.1162/DRAM_a_00493.

Spencer, Charlotte. 2017a. "Don't just watch dance, become part of the show, go outside, put on some headphones and perform in Is this a Waste Land?" Interview by Savannah Saunders. The 
Wonderful World of Dance, May 1, 2017. Audio, 36:34. Accessed November 7, 2017.

http://www.thewonderfulworldofdance.com/is-this-a-wasteland-charlotte-spencer.

Spencer, Charlotte. 2017b. “Is this a Waste Land?” Program notes. May 12-14, 2017. Glasgow: Tramway, Larkfield Bus Depot.

Thiele, Kathrin. 2014. "Ethos of Diffraction: New Paradigms for a (Post)humanist Ethics.” Parallax 20 (3): 202-216. https://doi.org/10.1080/13534645.2014.927627.

Thiele, Kathrin. 2016. "Quantum Physics and/as Philosophy: Immanence, Diffraction, and the Ethics of Mattering.” Rhizomes: Cultural Studies in Emerging Knowledge 30. https://doi.org/10.20415/rhiz/030.e04.

White, Gareth. 2013. Audience Participation in Theatre: Aesthetics of the Invitation. Basingstoke: Palgrave Macmillan.

\section{Notes}

1 As I will discuss in the following paragraphs, I use the term "im/possibility" in this article drawing on Karen Barad's new materialist epistemology and terminology, "where the slash is indicating an active and reiterative (intra-active) rethinking of the binary" (Barad in interview: Juelskjaer and Schwennesen 2012, 19).

2 While I cannot claim specialist knowledge of science, technology and quantum physics, I am empowered by Barad's acknowledgement of and openness to a "less scientifically inclined" 
readership (Barad 2007, 37), which I take to imply that the notions of diffraction and intraaction can be understood to be of broader epistemological, cultural and ethical significance. 3 It is beyond the scope of this article to discuss definitions of neoliberalism and interpretations of how recent choreography may be seen to respond to the socio-political conditions of late capitalism. In an earlier article I offer an analysis of choreographic works by Alessandro Sciarroni and by Igor and Moreno, arguing that they engage both critically and affectively with the erosion of social cohesion that characterise the immaterial economies of financial capitalism (Perazzo Domm 2018).

4 For an interrogation of how performance practices articulate critical responses to times, experiences and understandings of crisis, see also the issue of Performance Philosophy on “crisis/krisis" (Daddario and Schmidt 2018).

5 Having lived in Italy until my early adulthood, I moved to the UK over fifteen years ago, via prolonged residencies in Brussels and Berlin.

6 Further discussion of how 52 Portraits articulates ideas of community is provided in my monograph Jonathan Burrows: Towards a Minor Dance (Palgrave Macmillan, expected in 2020).

7 The new materialist concept of diffraction is as yet underexplored in performance and dance scholarship. Through this contribution, I advocate its productive implications in the interrogation of how dance's thinking-practice unfolds through and exposes multiple and overlapping modalities.

8 Spencer is a choreographer based in Sussex, South East England, who devises movementbased works and projects for outdoor spaces and diverse audiences. Since 2015, I have followed Spencer's work closely, gaining insight into her creative process. In April 2016, I was invited to take part in an early sharing of Is this a Waste Land?, which took place at London's Olympic Park. The description of the work I offer in this article refers to the work's premiere a year later. 
9 Further iterations of the work took place in Glasgow's abandoned Larkfield Bus Depot as part of "Dance International Glasgow" in May 2017 and on a site near London City Airport as part of the "Dance Umbrella" festival in October 2017.

10 An in-depth discussion of the tradition of immersive and participatory performance practices - as outlined for instance by White (2013) and Harpin and Nicholson (2016) - is beyond the scope of this article. In this context, it will suffice to position my understanding of immersion as a broad category informed by Jacques Rancière's redistribution of the roles of acting and viewing, through his idea of emancipated spectatorship (Rancière 2009). Elsewhere (Perazzo Domm 2017), I offer further contextualization of Spencer's earlier work Walking Stories (2013) within this tradition.

11 In my earlier article on Spencer's work (Perazzo Domm 2017), I discuss how Spencer's Walking Stories uses audio technology to engage with poietic strategies through which time and space are "made." Unpicking the notion of "moving poetry," I focus on the transformative possibilities of choreographic practices in which movement and words intersect.

12 My analysis of Is this a Waste Land? is crucially informed by discussions with Spencer, Jennifer-Lynn Crawford and Arabella Stanger, produced on the occasion of our roundtable presentation "Disuse, Poiesis, Blockage: A Roundtable on Choreographic Space" at the “Between Spaces Symposium”, University of Chichester, June 2017. In particular, Stanger's reflections on the archaeological dimension of public spaces drew attention to how historicity and materiality are mutually constituted.

13 The piece premiered in the UK in 2016. I saw it at The Place, London, in April 2017, and then again at Tate Britain, London, in August 2017.

14 See for instance Farnham Maltings (2015).

15 Quantum theory's focus on matter as indeterminate and radically open supports the conceptualization of touching as always involving the other, including the other (and the inhuman) within oneself. 
16 For instance, we hear a voice recording of the American psychologist Carl Rogers (1902 - 87) encouraging us to "take a fresh look at empathy." 